\title{
Evaluation of Anti-Inflammatory Activity of Pseudananas macrodontes (Morr.) Harms (Bromeliaceae) Fruit Extract in Rats
}

\author{
María E. Errasti ${ }^{\mathrm{a}, *}$, Néstor O. Caffini ${ }^{\mathrm{a}}$, Lilian E. Pelzer ${ }^{\mathrm{b}}$, and Alejandra E. Rotellib \\ a Laboratory of Plant Proteins, Faculty of Exact Sciences, National University of La Plata, \\ 47 \& 115, 1900 La Plata, Argentina. Fax: +54 221 4226947. E-mail: caffini@biol.unlp.edu.ar \\ b Laboratory of Pharmacology, Faculty of Chemistry, Biochemistry and Pharmacy, \\ National University of San Luis, Chacabuco \& Pedernera, 5700 San Luis, Argentina \\ * Author for correspondence and reprint requests \\ Z. Naturforsch. 68c , 445-452 (2013); received September 26, 2012/October 25, 2013
}

Several species of the family Bromeliaceae are characterized by the production of proteases in unusual amounts, especially in fruits. Bromelain, an extract rich in cysteine endopeptidases obtained from Ananas comosus L., and a few other proteases have been used as anti-inflammatory agents for some years, but bromelain is still mainly being used as alternative and/or complementary therapy to the treatment with glucocorticoids, nonsteroidal antirheumatics, and immunomodulators. In this study, the anti-inflammatory action of a partially purified extract from Pseudananas macrodontes (Morr.) Harms fruits $\left(\mathrm{PPE}_{\mathrm{Pm}}\right)$ is presented, whose main components are cysteine endopeptidases. The effect of $\mathrm{PPE}_{\mathrm{Pm}}$ was assessed in carrageenan-induced and serotonin-induced rat paw edema, as well as in the cotton pellet granuloma model. Doses with equal proteolytic activity of $\mathrm{PPE}_{\mathrm{Pm}}$ and bromelain produced significantly similar anti-inflammatory responses in the acute inflammatory models assayed, supporting the hypothesis that proteolytic activity could be responsible for the anti-inflammatory action. On the contrary, comparable anti-inflammatory effects of $\mathrm{PPE}_{\mathrm{Pm}}$ and bromelain in the chronic inflammatory assay required a much lower proteolytic activity content of $\mathrm{PPE}_{\mathrm{Pm}}$, which could be due to a differential affinity for the protein target involved in this process.

Key words: Anti-Inflammatory, Pseudananas macrodontes, Plant Proteases

\section{Introduction}

Many inflammatory diseases are becoming common in aging societies throughout the world. The clinically used anti-inflammatory drugs suffer from the disadvantage of side effects and high cost of treatment (in case of biologics). Alternatives to these drugs are traditional medicines and natural products, which offer a great hope in the identification of bioactive lead compounds and their development into drugs for treating inflammatory diseases (Gautam and Jachak, 2009). Many plant species and their products exhibiting experimental or clinical anti-inflammatory or analgesic activities have been recently reviewed (Anilkumar, 2010), one of the best examples being acetylsalicylic acid (aspirin) derived from the bark of Salix alba (Gómez Estrada et al., 2011).

Several species of the family Bromeliaceae are characterized by the production of proteases in unusually high amounts, particularly in their fruits, probably with a role in defence responses (Boller, 1986; van der Hoorn and Jones, 2004). Bromelain, an extract rich in cysteine endopeptidases obtained from Ananas comosus L. (Bromeliaceae) stems, has been shown to have both in vivo and in vitro antiedematous, anti-inflammatory, anticoagulant, and fibrinolytic effects and is employed in therapies alternative and/or complementary to treatments with glucocorticoids, nonsteroidal antirheumatics, and immunomodulators. Its low toxicity makes it also useful in the treatment of chronic inflammation (Maurer, 2001). In therapeutic use, bromelain is orally administered alone or together with rutin and/or other enzymes such as trypsin, chymotrypsin, pancreatin, papain, lipases, and amylases (Brien et al., 2004).

The anti-inflammatory activity of bromelain involves an increase in the fibrinolytic activity, enhancement of plasmin concentration by activation of the conversion of plasminogen to plasmin, decrease of the levels of plasma fibrinogen, bradykinin, and prekallikrein (Maurer, 2001), decrease of prostaglandin $\mathrm{E}_{2}\left(\mathrm{PGE}_{2}\right)$, thromboxane $\mathrm{A}_{2}$, and substance P levels (Vellini et al., 1986; Gaspani et 
$a l ., 2002)$, as well as the modulation of cell surface molecules involved in migration (Fitzhugh et al., 2008) and cellular activation (Hale and Haynes, 1992; Mynott et al., 1999; Hale et al., 2002), and reduction of cyclooxygenase-2 (COX-2) expression by inhibing the activation of nuclear factor kappa-B (NF-KB) (Bhui et al., 2011). Even though the mechanism of the anti-inflammatory action of bromelain has not yet been definitively elucidated, its proteolytic activity appears to be implicated (Fitzhugh et al., 2008; Hale and Haynes, 1992; Mynott et al., 1999; Hale et al., 2002, 2005). For ficin and bromelain, Netti et al. (1972) found the degree of the inhibition of rat paw edema induced by different agents - carrageenan, serotonin, dextran, and brewer's yeast - similar or better than that achieved with indomethacin, acetylsalicylic acid, and phenylbutazone.

Two cysteine endopeptidases, viz. macrodontain I and II, have been isolated from Pseudananas macrodontes (Morr.) Harms fruits and characterized by us (López et al., 2001). The N-terminal sequences of both proteases (including the Cys 26 of the active site) show a high degree of identity $(92.6 \%)$, as differences in only two residues are observed. Macrodontain I possesses $85.7 \%$ identity with comosain, $85.2 \%$ with stem bromelain, and $77.8 \%$ identity with ananain, while macrodontain II possesses $88.9 \%$ identity with stem bromelain, $77.8 \%$ with ananain, and $76.2 \%$ with comosain (López et al., 2001). The primary structure of macrodontain I is composed of 213 amino acids (UniProtKB/Swiss-Prot entry P83443; molecular mass, 23,486 Da), and the alignment with other plant cysteine peptidases revealed that the highest degree of identity (77\%) was obtained with fruit bromelain, followed by ananain $(71.9 \%)$, and stem bromelain (67.1\%) (Brullo, 2003).

In this study, the anti-inflammatory action of a partially purified extract of $P$. macrodontes fruits $\left(\mathrm{PPE}_{\mathrm{Pm}}\right)$ and its comparison with the action of bromelain in acute and chronic inflammation models was examined.

\section{Material and Methods}

\section{Chemicals}

Bromelain (B4882), carrageenan type IV, casein (from bovine milk), Coomassie brilliant blue G-250, cysteine, indomethacin (> 99\%), serotonin, and Tris were purchased from Sigma-Aldrich (St. Louis, MO, USA). Ethylenediaminetetraacetic acid (EDTA) was purchased from Invitrogen (Carlsbad, CA, USA), sodium phosphate (98\%) from Carlo Erba (Rodano, MI, Italy), ketamine chlorohydrate $(50 \mathrm{mg} / \mathrm{mL})$ from Holliday Scott (Beccar, BA, Argentina), xylazine chlorohydrate $(10 \mathrm{mg} / \mathrm{mL})$ from Richmond Laboratories Vet Pharma (Buenos Aires, Argentina), and dexamethasone sodium phosphate $(4 \mathrm{mg} / \mathrm{mL})$ from Laboratorios Klonal (Quilmes, BA, Argentina).

\section{Plant material}

Pseudananas macrodontes fruits were collected in Santa Ana, Department of Candelaria, Province of Misiones, Argentina (latitude, S 27 $23^{\prime}$; longitude, W $55^{\circ} 33^{\prime}$ ), by Prof. Aníbal G. Amat. A voucher specimen (Leg. Amat, No. 1596) was deposited at the herbarium of the Faculty of Exact, Chemical and Natural Sciences of the National University of Misiones (MNES), Misiones, Argentina. Fruits were washed with distilled water, dried, and stored at $-20{ }^{\circ} \mathrm{C}$ until extraction.

\section{Preparation of plant extract}

Crude and partially purified extracts were obtained according to López et al. (2000), with some modifications. Frozen unripe fruits $(120 \mathrm{~g})$ were chopped and homogenized with $600 \mathrm{~mL}$ of 0.1 m sodium phosphate buffer ( $\mathrm{pH}$ 6.0) containing $5 \mathrm{~mm}$ EDTA and $5 \mathrm{~mm}$ cysteine as protective agents. The homogenate was filtered and centrifuged at 5,000 x $g$ for $30 \mathrm{~min}$. The supernatant (crude extract) was collected, filtered, and stored at $-20^{\circ} \mathrm{C}$ until use. Then, to one volume of crude extract one volume of cold $\left(-20^{\circ} \mathrm{C}\right) 96 \%$ ethanol was added during $30 \mathrm{~min}$ at $0{ }^{\circ} \mathrm{C}$ and the mixture centrifuged at $12,000 \times \mathrm{g}$ for $30 \mathrm{~min}$. The precipitate was discarded, and three volumes of cold ethanol were added to the supernatant during $2 \mathrm{~h}$ at $0{ }^{\circ} \mathrm{C}$; the resulting mixture was centrifuged at $12,000 \mathrm{x} g$ for $30 \mathrm{~min}$. The ethanol precipitate was redissolved in $0.1 \mathrm{~m}$ sodium phosphate buffer $(\mathrm{pH}$ 6.0) after evaporation of the solvent in vacuo. Finally, the partially purified extract, named $\mathrm{PPE}_{\mathrm{Pm}}$, was lyophilized and stored at $-20{ }^{\circ} \mathrm{C}$.

\section{Extract characterization}

Assays on caseinolytic activity ( $1 \%$ casein, $0.1 \mathrm{~m}$ Tris- $\mathrm{HCl}$ buffer, $\mathrm{pH} 7.5,37^{\circ} \mathrm{C}, 2 \mathrm{~min}$ ) were carried out to determine the proteolytic activity of $\mathrm{PPE}_{\mathrm{Pm}}$. An arbitrary enzyme unit (caseinolytic 
unit, CU) was used to express the proteolytic activity (López et al., 2000). The protein content was determined by the method of Bradford (1976), using bovine serum albumin as standard.

\section{Animals}

Wistar albino rats were purchased, housed, and cared for at the Animal Resource Facilities, Faculty of Chemistry, Biochemistry and Pharmacy, National University of San Luis, San Luis, Argentina. The experimental protocols were approved by the Laboratory Animal Care and Use Institutional Committee in compliance with Argentine official resolutions for animal care guidelines (ANMAT No. 6344/96). Animals were randomly assigned to different groups $(n=6)$, provided with standard rodent chow diet (Cooperación, Buenos Aires, Argentina) and water ad libitum, and maintained at a constant temperature of $(24 \pm 1){ }^{\circ} \mathrm{C}$ and a humidity of $(55 \pm 5) \%$ under a 12-h light/12-h dark cycle.

\section{Drug administration}

$\mathrm{PPE}_{\mathrm{Pm}}$ doses were prepared by dissolving the lyophilized powder in sterile water. The dose of bromelain was prepared by dissolving the commercial material in $0.1 \mathrm{M}$ sodium phosphate buffer (pH 6.0). All doses (0.5 mL) were administered intraperitoneally (i.p.).

\section{Carrageenan-induced paw edema in rats}

Anti-inflammatory activity was assessed on paw edema induced by carrageenan, following the method described by Winter et al. (1962). Male Wistar rats, weighing 170-220 g, were divided into five groups $(n=6)$ : two groups received $\mathrm{PPE}_{\mathrm{Pm}}$ [90 and $180 \mathrm{mg} / \mathrm{kg}$ body weight $(\mathrm{BW})]$, the control group received $0.1 \mathrm{M}$ sodium

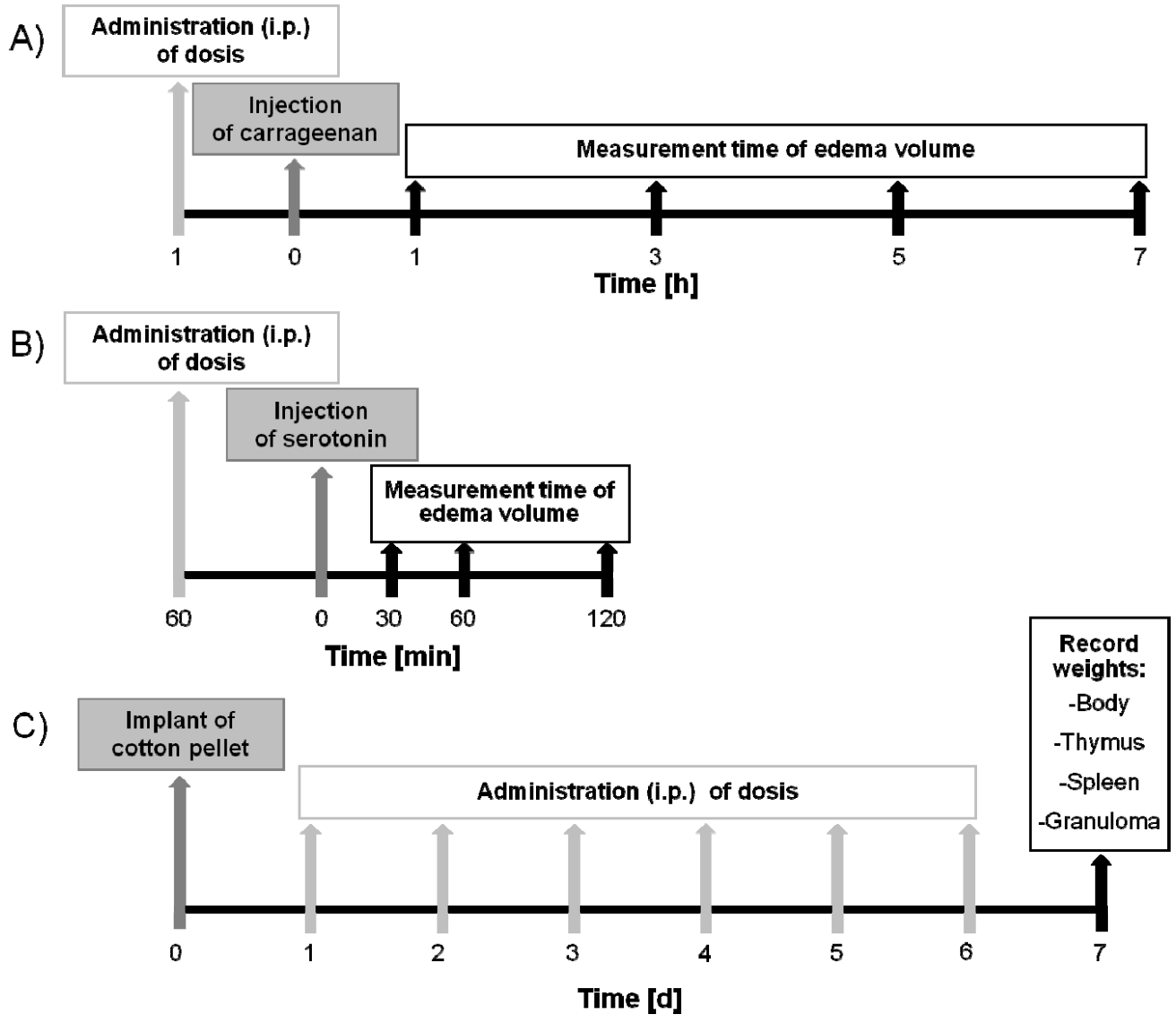

Fig. 1. Model design and dosing routines for rats in (A) carrageenan-induced paw edema, (B) serotonin-induced paw edema, and (C) cotton pellet-induced granuloma. 
phosphate buffer ( $\mathrm{pH} 6.0$ ), one of the reference groups received indomethacin $(10 \mathrm{mg} / \mathrm{kg} \mathrm{BW})$, and the other one received bromelain $(50 \mathrm{mg} / \mathrm{kg}$ $\mathrm{BW})$. One $\mathrm{h}$ later, $0.1 \mathrm{~mL}$ of $2 \%(\mathrm{w} / \mathrm{v})$ carrageenan type IV suspended in saline was injected into the subplantar region of the left hind paw of each rat. Volumes of both hind paws were measured in triplicate using a plethysmograph (Ugo Basile, Varese, Italy) at $1,3,5$, and $7 \mathrm{~h}$ after injection of carrageenan (Fig. 1A). The edema volume was expressed as the difference between the average volumes of the two hind paws. The inhibition percentage of edema was calculated for each group in comparison with the control group as $\left(1-V_{\mathrm{t}} /\right.$ $\left.V_{\mathrm{c}}\right) \cdot 100$, where $V_{\mathrm{c}}$ and $V_{\mathrm{t}}$ are the edema average volumes of control and treated groups, respectively.

\section{Serotonin-induced paw edema in rats}

Male Wistar rats, weighing 200-220 g, were divided into three groups $(n=6)$ : one group received $\mathrm{PPE}_{\mathrm{Pm}}(180 \mathrm{mg} / \mathrm{kg} \mathrm{BW})$, the control group received $0.1 \mathrm{M}$ sodium phosphate buffer $(\mathrm{pH}$ 6.0 ), and the reference group received bromelain $(50 \mathrm{mg} / \mathrm{kg} \mathrm{BW})$. One $\mathrm{h}$ after drug administration, all groups received a subplantar injection of $0.1 \mathrm{~mL}$ of $0.01 \%$ serotonin solution in normal saline (Kalbhem and Smalla, 1977). Edema volume was measured at 30,60 , and 120 min after injection of serotonin following the same procedure used in the carrageenan-induced edema method (Fig. 1B). Percent inhibition of edema was calculated as mentioned above.

\section{Cotton pellet-induced granuloma in rats}

The assay was carried out following the method of Meier et al. (1950). Female Wistar rats, weighing $115-150 \mathrm{~g}$, were anaesthetized by i.p. injection of a mixture of ketamine chlorohydrate $(75 \mathrm{mg} /$ $\mathrm{kg} \mathrm{BW})$ and xylazine chlorohydrate $(12 \mathrm{mg} / \mathrm{kg}$ BW). Granuloma was induced in all animals by a subcutaneous implant of a sterile cotton pellet $(50 \mathrm{mg})$ in the dorsal area. One d later, animals were divided into four groups and i.p. inoculated once daily during $6 \mathrm{~d}$ as follows: one group received $\mathrm{PPE}_{\mathrm{Pm}}(60 \mathrm{mg} / \mathrm{kg} \mathrm{BW})$, the control group received $0.1 \mathrm{~m}$ sodium phosphate buffer $(\mathrm{pH} 6.0)$, one reference group received bromelain $(50 \mathrm{mg}$ / $\mathrm{kg} \mathrm{BW})$, and the other one dexamethasone (4 mg/ $\mathrm{kg} \mathrm{BW}$ ). On day 7, body weight was recorded, and the animals were sacrificed by cervical dislocation.
The pellets surrounded by granuloma tissue were removed and weighed. Spleen and thymus were dissected out and weighed. The anti-inflammatory effect was assessed by determining the inhibition percentage of granuloma formation in the groups under study as compared with the control as follows: $\left(1-m_{\mathrm{t}} / m_{\mathrm{c}}\right) \cdot 100$, where $m_{\mathrm{c}}$ and $m_{\mathrm{t}}$ are the average weights of control and treated groups, respectively. Reduction percentage of thymus and spleen weights was calculated with the same formula. Body weight change was calculated as the difference between final and initial body weights. Fig. 1C shows model design and dosing routines.

\section{Statistical analysis}

The GraphPadPrism software version 5.0 was used for statistical analysis. Data obtained are presented as mean \pm SEM. Raw data (edema volume and weights) were analysed with Oneway ANOVA followed by Tukey's Multiple Comparison test. A probability of $p<0.05$ was considered significant.

\section{Results and Discussion}

The protein content of the partially purified extract obtained from Pseudananas macrodontes fruits $\left(\mathrm{PPE}_{\mathrm{Pm}}\right)$ was $(28 \pm 2) \mu \mathrm{g} / \mathrm{mg}$ of lyophilized powder, and its specific enzymatic activity was $(5.6 \pm 0.4) \mathrm{CU} / \mathrm{mg}$ of protein $\left(37^{\circ} \mathrm{C}, \mathrm{pH} 7.5\right)$. In the case of stem bromelain (B4882), the protein content was $(200 \pm 12) \mu \mathrm{g} / \mathrm{mg}$ of commercial powder, and specific enzymatic activity was $(3.2 \pm 0.2) \mathrm{CU} / \mathrm{mg}$ of protein $\left(37^{\circ} \mathrm{C}, \mathrm{pH} 7.5\right)$.

Edema formation is one the events that happen during acute inflammatory response and is the result of changes in the microvasculature of the inflamed area. Carrageenan-induced rat paw edema is a model of acute inflammation widely used to determine the anti-inflammatory activity of drugs, and doses of nonsteroidal anti-inflammatory drugs (NSAIDs) in this test correlated well with effective doses in patients (Morris, 2003). Table I shows the effects of $\mathrm{PPE}_{\mathrm{Pm}}(90$ and $180 \mathrm{mg} / \mathrm{kg} \mathrm{BW})$, bromelain $(50 \mathrm{mg} / \mathrm{kg} \mathrm{BW})$, and indomethacin $(10 \mathrm{mg} /$ $\mathrm{kg} \mathrm{BW}$ ) administration on carrageenan-induced paw edema in rats. Both $\mathrm{PPE}_{\mathrm{Pm}}$ doses elicited an anti-inflammatory effect: the lower one $(90 \mathrm{mg} /$ $\mathrm{kg} \mathrm{BW}$ ) significantly inhibited edema formation after $3 \mathrm{~h}$, reaching maximum relative inhibition (about $45 \%$ ) between 3 and $5 \mathrm{~h}$ after carrageenan 
Table I. Effect of $\mathrm{PPE}_{\mathrm{Pm}}$, bromelain, and indomethacin on carrageenan-induced paw edema in rats.

\begin{tabular}{|c|c|c|c|c|c|c|c|c|c|}
\hline \multirow[t]{2}{*}{$\begin{array}{c}\text { Time } \\
{[\mathrm{h}]}\end{array}$} & \multirow{2}{*}{$\begin{array}{c}\text { Control } \\
\text { Edema } \\
\text { volume } \\
{[\mathrm{mL}]} \\
\end{array}$} & \multicolumn{2}{|c|}{$\begin{array}{c}\mathrm{PPE}_{\mathrm{Pm}} \\
{[90 \mathrm{mg} / \mathrm{kg} \mathrm{BW}=} \\
(15 \pm 1) \mathrm{CU} / \mathrm{kg} \mathrm{BW}]\end{array}$} & \multicolumn{2}{|c|}{$\begin{array}{c}\mathrm{PPE}_{\mathrm{Pm}} \\
{[180 \mathrm{mg} / \mathrm{kg} \mathrm{BW}=} \\
(31 \pm 2) \mathrm{CU} / \mathrm{kg} \mathrm{BW}]\end{array}$} & \multicolumn{2}{|c|}{$\begin{array}{c}\text { Bromelain } \\
{[50 \mathrm{mg} / \mathrm{kg} \mathrm{BW}=} \\
(32 \pm 2) \mathrm{CU} / \mathrm{kg} \mathrm{BW}] \\
\end{array}$} & \multicolumn{2}{|c|}{$\begin{array}{l}\text { Indomethacin } \\
(10 \mathrm{mg} / \mathrm{kg} \mathrm{BW})\end{array}$} \\
\hline & & $\begin{array}{l}\text { Edema } \\
\text { volume } \\
{[\mathrm{mL}]}\end{array}$ & $\begin{array}{c}\text { Inhibition } \\
(\%)\end{array}$ & $\begin{array}{l}\text { Edema } \\
\text { volume } \\
{[\mathrm{mL}]}\end{array}$ & $\begin{array}{c}\text { Inhibition } \\
(\%)\end{array}$ & $\begin{array}{l}\text { Edema } \\
\text { volume } \\
{[\mathrm{mL}]}\end{array}$ & $\begin{array}{c}\text { Inhibition } \\
(\%)\end{array}$ & $\begin{array}{l}\text { Edema } \\
\text { volume } \\
{[\mathrm{mL}]}\end{array}$ & $\begin{array}{c}\text { Inhibition } \\
(\%)\end{array}$ \\
\hline 1 & $0.27 \pm 0.03$ & $0.19 \pm 0.02$ & 29 & $0.12 \pm 0.02$ & $55_{\mathrm{b}} * * *$ & $0.18 \pm 0.02$ & $33_{\mathrm{bc}}$ & $0.24 \pm 0.02$ & $11_{c}$ \\
\hline 3 & $0.64 \pm 0.07$ & $0.35 \pm 0.04$ & $45_{\mathrm{ba}} * *$ & $0.19 \pm 0.02$ & $70_{\mathrm{b}} * * *$ & $0.29 \pm 0.03$ & $55_{\mathrm{b}} * * *$ & $0.55 \pm 0.06$ & $14_{\mathrm{ca}}$ \\
\hline 5 & $1.14 \pm 0.08$ & $0.6 \pm 0.2$ & $47_{\mathrm{b}} * *$ & $0.23 \pm 0.02$ & $80_{\mathrm{b}} * * *$ & $0.28 \pm 0.02$ & $75_{\mathrm{b}} * * *$ & $0.38 \pm 0.03$ & $67_{\mathrm{b}} * * *$ \\
\hline 7 & $1.3 \pm 0.1$ & $0.8 \pm 0.2$ & $38_{a}^{*}$ & $0.20 \pm 0.02$ & $85_{\mathrm{b}} * * *$ & $0.45 \pm 0.04$ & $65_{\mathrm{d}} * * *$ & $0.55 \pm 0.04$ & $58_{\mathrm{ad}} * * *$ \\
\hline
\end{tabular}

Edema volumes are expressed as the mean \pm SEM $(n=6)$. Inhibition $(\%)$ represents the mean percentage reduction in paw volume relative to controls. Tukey's test: $* p<0.05, * * p<0.01, * * * p<0.001$ compared to the control group; the means with a common subscript letter are not significantly different at $p<0.05$.

administration, while the higher one $(180 \mathrm{mg} / \mathrm{kg}$ BW) inhibited after $1 \mathrm{~h}$, reaching the maximum effect (about $80 \%$ ) between 5 and $7 \mathrm{~h}$ after carrageenan administration. Bromelain was significantly anti-inflammatory after $3 \mathrm{~h}$ and exhibited maximum inhibition (about $75 \%$ ) after $5 \mathrm{~h}$ of carrageenan administration. Indomethacin showed significant anti-inflammatory activity 5 and $7 \mathrm{~h}$ after carrageeenan administration.

Edema development in this model has been described as a biphasic process (Vinegar et al., 1969; Salvemini et al., 1996). The initial phase of edema formation $(0-1 \mathrm{~h})$, which is not inhibited by NSAIDs, is attributed to the release of histamine and serotonin (Di Rosa et al., 1971). The second phase $(1-6 \mathrm{~h})$ is associated with a local infiltration and activation of neutrophils (Boughton-Smith et al., 1993) and the production of prostaglandins (Di Rosa et al., 1971), which has been attributed to the induction of COX-2 (Nantel et al., 1999). An increase in NO production is also associated with the increase of paw volume (Salvemini et al., 1996).
Although $\mathrm{PPE}_{\mathrm{Pm}}(180 \mathrm{mg} / \mathrm{kg} \mathrm{BW})$ had a significant anti-inflammatory effect from the first hour after injection of carrageenan, the maximum inhibition was reached $5 \mathrm{~h}$ after carrageenan administration, as in the case of bromelain and indomethacin. All doses tested produced significant inhibition after $7 \mathrm{~h}$. It is known that indomethacin inhibits prostaglandins production (by inhibition of COX-1), while bromelain, in other experimental models, has been shown to reduce the production of NO (Wen et al., 2006) and prostaglandins (Bhui et al., 2011), as well as neutrophil migration (Fitzhugh et al., 2008). These results allow us to conclude that $\mathrm{PPE}_{\mathrm{Pm}}$ acts preferentially on the second rather than the first phase of carrageenaninduced edema, which could be explained by a better bioavailability and/or increased specificity against the release/action of mediators involved in the second phase (neutrophils, prostaglandins, and NO), whose production usually peaks between 3 and $6 \mathrm{~h}$ after injection of carrageenan (Salvemini et al., 1996).

Table II. Effect of $\mathrm{PPE}_{\mathrm{Pm}}$ and bromelain on serotonin-induced paw edema in rats.

\begin{tabular}{|c|c|c|c|c|c|}
\hline \multirow[t]{2}{*}{$\begin{array}{l}\text { Time } \\
{[\mathrm{min}]}\end{array}$} & \multirow{2}{*}{$\begin{array}{l}\text { Control } \\
\text { Edema } \\
\text { olume [mL] }\end{array}$} & \multicolumn{2}{|c|}{$\begin{array}{c}\mathrm{PPE}_{\mathrm{Pm}} \\
{[180 \mathrm{mg} / \mathrm{kg} \mathrm{BW}=} \\
(31 \pm 2) \mathrm{CU} / \mathrm{kg} \mathrm{BW}]\end{array}$} & \multicolumn{2}{|c|}{$\begin{array}{c}\text { Bromelain } \\
{[50 \mathrm{mg} / \mathrm{kg} \mathrm{BW}=} \\
(32 \pm 2) \mathrm{CU} / \mathrm{kg} \mathrm{BW}]\end{array}$} \\
\hline & & $\begin{array}{c}\text { Edema } \\
\text { volume }[\mathrm{mL}]\end{array}$ & $\begin{array}{c}\text { Inhibition } \\
\text { (\%) }\end{array}$ & $\begin{array}{c}\text { Edema } \\
\text { volume }[\mathrm{mL}]\end{array}$ & $\begin{array}{c}\text { Inhibition } \\
(\%)\end{array}$ \\
\hline 30 & $1.05 \pm 0.07$ & $0.75 \pm 0.11$ & $29 *$ & $0.52 \pm 0.03$ & $50_{a} * * *$ \\
\hline 60 & $0.87 \pm 0.07$ & $0.68 \pm 0.12$ & $22_{\mathrm{ca}}$ & $0.50 \pm 0.04$ & $422^{*} *$ \\
\hline 120 & $0.67 \pm 0.06$ & $0.56 \pm 0.11$ & $20_{\mathrm{c}}$ & $0.46 \pm 0.04$ & $31_{\mathrm{c}}$ \\
\hline
\end{tabular}

Edema volumes are expressed as the mean $\pm \operatorname{SEM}(n=6)$. Inhibition $(\%)$ represents the mean percentage reduction in paw volume relative to controls. Tukey's test: $* p<0.05, * * * p<0.001$ compared to the control group; the means with a common subscript letter are not significantly different at $p<0.05$. 
To evaluate the action of $\mathrm{PPE}_{\mathrm{Pm}}$ on the early development of edema, the serotonin-induced edema assay was carried out. Table II shows the results of $\mathrm{PPE}_{\mathrm{Pm}}(180 \mathrm{mg} / \mathrm{kg} \mathrm{BW})$ and bromelain $(50 \mathrm{mg} / \mathrm{kg}$ BW) administration on serotonininduced paw edema in rats. $\mathrm{PPE}_{\mathrm{Pm}}$ significantly inhibited edema formation (29\%) 30 min after serotonin injection, which was not significantly different from the action of bromelain (50\%). Also, bromelain exhibited significant anti-inflammatory activity (42\%) 60 min after injection.

Granulomatous inflammation is a morphological type of chronic state of inflammation, and the cotton pellet-induced granuloma in rats is a representative model for studying drugs against this inflammation phase (Bailey et al., 1982). Anti-inflammatory action of $\mathrm{PPE}_{\mathrm{Pm}}$ was assayed in this model and compared with that of bromelain and dexamethasone. $\mathrm{PPE}_{\mathrm{Pm}}(60 \mathrm{mg} / \mathrm{kg} \mathrm{BW})$ and bromelain $(50 \mathrm{mg} / \mathrm{kg} \mathrm{BW})$ were similarly effective in the cotton pellet-induced granuloma assay (Fig. 2). $\mathrm{PPE}_{\mathrm{Pm}}$, bromelain, and dexamethasone (4 mg/kg BW) significantly reduced granuloma formation relative to the control at day 7 , inhibiting 26,24 , and $54 \%$, respectively. Values for $\mathrm{PPE}_{\mathrm{Pm}}$ and bromelain were not significantly different from each other, but were significantly lower than that for dexamethasone. In addition, some side effects, common to long-term glucocorticoid therapy, were evaluated: the immunosuppressive action, by weighing thymus and spleen (Ben Rhouma and Sakly, 1994; Hori et al., 1996), and the catabolic effect, by measuring the loss of body mass. While dexamethasone caused signifi-

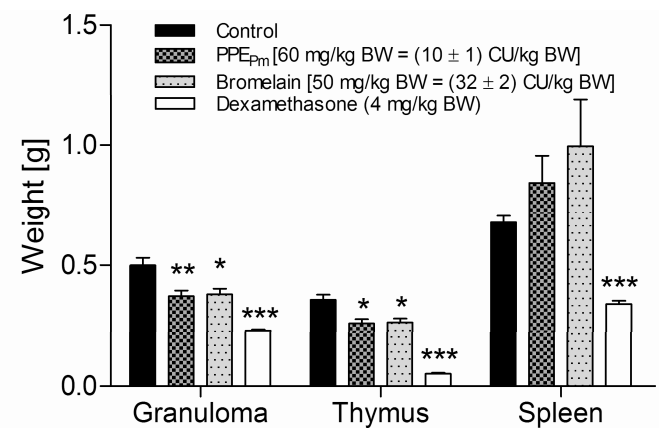

Fig. 2. Effect of $\mathrm{PPE}_{\mathrm{Pm}}$, bromelain, and dexamethasone on the formation of cotton pellet-induced granuloma and weights of thymus and spleen in rats. Values are expressed as the mean \pm SEM $(n=6)$. Tukey's test: $* p<0.05, * * p<0.01, * * * p<0.001$ compared to the control group. cant atrophy of spleen and thymus (50 and 86\%, respectively), bromelain and $\mathrm{PPE}_{\mathrm{Pm}}$ only reduced thymus weight to the same low degree (26\%). On the other hand, changes in body weight in the control group and those treated with $\mathrm{PPE}_{\mathrm{Pm}}$ and bromelain were not significantly different. Body weight increments at the end of the assay were $15 \mathrm{~g}$ for the control group, and 17 and $15 \mathrm{~g}$ for $\mathrm{PPE}_{\mathrm{Pm}}$ - and bromelain-treated groups, respectively. In contrast, dexamethasone produced a significant body weight loss $(-11 \mathrm{~g})$.

These results are promising for the application of proteolytic preparations in the long-term treatment of chronic diseases; however, toxicological tests are required to confirm this view. Sixty $\mathrm{mg}$ $\mathrm{PPE}_{\mathrm{Pm}} / \mathrm{kg} \mathrm{BW}$ was the dose of choice, because $33 \%$ mortality was observed with a dose of $180 \mathrm{mg} / \mathrm{kg}$ BW (data not shown). On the other hand, taking into account the predominant role of T-cells in the development of granulomatous inflammation (Co et al., 2004) and the slight thymic atrophy that accompanies the inhibition of granuloma formation by $\mathrm{PPE}_{\mathrm{Pm}}$ and bromelain, also observed for Bromelia hieronymi extracts (Errasti et al., 2013), one might assume that part of the anti-inflammatory action involves the regulation of T-cell activity.

Since the anti-inflammatory mechanism of bromelain has been attributed to its proteolytic activity (Fitzhugh et al., 2008; Hale and Haynes, 1992; Mynott et al., 1999; Hale et al., 2000, 2005), the higher dose of $\mathrm{PPE}_{\mathrm{Pm}}$ (on weight basis) in the acute inflammatory assays was chosen to contain proteolytic activity equal to that of bromelain $(\approx 30 \mathrm{CU} / \mathrm{kg} \mathrm{BW})$. The observation that, on this basis, the effects of the two preparations were significantly similar, supports the notion that proteases are responsible for their anti-inflammatory activities. On the contrary, a much lower dose of $\mathrm{PPE}_{\mathrm{Pm}}[(10 \pm 1) \mathrm{CU} / \mathrm{kg} \mathrm{BW}]$ was sufficient to produce an anti-inflammatory effect comparable to that of bromelain $(32 \pm 2 \mathrm{CU} / \mathrm{kg} \mathrm{BW})$ in the chronic inflammatory assay, which could be due to differential affinities for the protein(s) critically involved in the latter process.

\section{Acknowledgements}

This work was supported by grants from ANPCyT (PICT 38088), Inter-U Program (MINCyT), National University of La Plata (Project X-445), and National University of San Luis (Project 8504). M. E. E. is a CONICET fellow. 
Anilkumar M. (2010), Ethnomedicinal plants as anti-inflammatory and analgesic agents. In: Ethnomedicine: A Source of Complementary Therapeutics (Chattopadhyay D., ed.). Research Signpost, Kerala, India, pp. $267-293$.

Bailey P. J., Sturm A., and Lopez-Ramos B. (1982), A biochemical study of the cotton pellet granuloma in the rat: Effects of dexamethasone and indomethacin. Biochem. Pharmacol. 31, 1213-1218.

Ben Rhouma K. and Sakly M. (1994), Involution of rat thymus: characterization of cytoplasmic glucocorticoid receptors, evidence of glucocorticoid resistant dexamethasone receptor-positive cells. Arch. Int. Physiol. Biochim. Biophys. 102, 97-102.

Bhui K., Tyagi S., Srivastava A. K., Singh M., Roy P. I., Singh R., and Shukla Y. (2011), Bromelain inhibits nuclear factor kappa-B translocation, driving human epidermoid carcinoma A431 and melanoma A375 cells through $\mathrm{G} 2 / \mathrm{M}$ arrest to apoptosis. Mol. Carcinog. 51, 231-243.

Boller T. (1986), Roles of proteolytic enzymes in interactions of plant with other organisms. In: Plant Proteolytic Enzymes, Vol. I (Dalling M. J., ed.). CRC Press, Boca Raton, FL, USA, pp. 68-96.

Boughton-Smith N. K., Deakin A. M., Follenfan R. L., Whittle B. J. R., and Garland L. G. (1993), Role of oxygen radicals and arachidonic acid metabolites in the reverse passive Arthus reaction and carrageenin paw oedema in the rat. Br. J. Pharmacol. 110, 896-902.

Bradford M. B. (1976), A rapid and sensitive method for the quantitation of microgram quantities of protein utilizing the principle of protein-dye binding. Anal. Biochem. 72, 248-254.

Brien S., Lewith G., Walker A., Hicks S. M., and Middleton M. (2004), Bromelain as a treatment for osteoarthritis: a review of clinical studies. Evid. Based Complement. Alternat. Med. 1, 251-257.

Brullo A. (2003), Aislamiento, purificación y caracterización de las endopeptidasas cisteínicas presentes en frutos de Pseudananas macrodontes (Morr.) Harms (Bromeliaceae). Ph. D. Thesis. National University of La Plata, Argentina. Available at http://sedici.unlp. edu.ar/bitstream/handle/10915/2246/Documento_ completo_.pdf? sequence $=23$.

Co D. O., Hogan L. H., Shin I.-K., and Sandor M. (2004), T-cell contributions to the different phases of granuloma formation. Immunol. Lett. 92, 135-142.

Di Rosa M., Giroud J. P., and Willoughby D. A. (1971), Studies of mediators of the acute inflammatory response induced in rats in different sites by carrageenin and turpentine. J. Pathol. 104, 15-29.

Errasti M. E., Caffini N. O., Pelzer L. E., and Rotelli A. E. (2013), Anti-inflammatory activity of Bromelia hieronymi: comparison with bromelain. Planta Med. 79, 207-213

Fitzhugh D. J., Shan S., Dewhirst M. W., and Hale L. P. (2008), Bromelain treatment decreases neutrophil migration to sites of inflammation. Clin. Immunol. 128, 66-74.

Gaspani L., Limiroli E., Ferrario P., and Bianchi M. (2002), In vivo and in vitro effects of bromelain on PGE(2) and SP concentrations in the inflammatory exudate in rats. Pharmacology 65, 83-86.
Gautam R. and Jachak S. M. (2009), Recent developments in anti-inflammatory natural products. Med. Res. Rev. 29, $767-820$.

Gómez Estrada H. A., González Ruiz K. N., and Domingo Medina J. (2011), Actividad antiinflamatoria de productos naturales. Bol. Latinoam. Caribe Plant Med. Aromat. 10, 182-217.

Hale L. P. and Haynes B. F. (1992), Bromelain treatment of human $\mathrm{T}$ cells removes CD44, CD45RA, E2/MIC, CD6, CD7, CD8, and Leu 8/ LAM1 surface molecules and markedly enhances CD2-mediated T cell activation. J. Immunol. 149, 3809-3816.

Hale L. P., Greer P. K., and Sempowski G. D. (2002), Bromelain treatment alters leukocyte expression of cell surface molecules involved in cellular adhesion and activation. Clin. Immunol. 104, 183-190.

Hale L. P., Greer P. K., Trinh C. T., and Gottfried M. R. (2005), Treatment with oral bromelain decreases colonic inflammation in the IL-10-deficient murine model of inflammatory bowel disease. Clin. Immunol. 116, 135-142.

Hori Y., Hu D.-E., Yasui K., Smither R. L., Austin Gresham G., and Fan T.-P. D. (1996), Differential effects of angiostatic steroids and dexamethasone on angiogenesis and cytokine levels in rat sponge implants. Br. J. Pharmacol. 118, 1584-1591.

Kalbhem D. and Smalla H. (1977), Pharmacological studies on the antiphlogistic effect of pentosanpolysulfate in combination with metamizol. Arzneimittelforschung 27, 1050-1057.

López L. M. I., Sequeiros C., Natalucci C. L., Brullo A., Maras B., Barra D., and Caffini N. O. (2000), Purification and characterization of macrodontain I, a cysteine peptidase from unripe fruits of Pseudananas macrodontes (Morr.) Harms (Bromeliaceae). Protein Expression Purif. 18, 133-140.

López L. M. I., Sequeiros C., Trejo S. A., Pardo M. F., Caffini N. O., and Natalucci C. L. (2001), Comparison of two cysteine endopeptidases from Pseudananas macrodontes (Morr.) Harms (Bromeliaceae). Biol. Chem. 382, 875-878.

Maurer H. R. (2001), Bromelain: biochemistry, pharmacology and medical use. Review. Cell. Mol. Life Sci. 58, 1234-1245.

Meier R., Schuler W., and Desaullis P. (1950), Zur Frage des Mechanismus der Hemmung des Bindegewebswachstums durch Cortisone. Experientia 6, 468-471.

Morris C. J. (2003), Carrageenan-induced paw edema in the rat and mouse. Methods Mol. Biol. 225, 115-121.

Mynott T. L., Ladhams A., Scarmato P., and Engwerda C. R. (1999), Bromelain from pineapple stems proteolytically blocks activation of extracellular regulated kinase-2 in T cells. J. Immunol. 163, 2568-2575.

Nantel F., Denis D., Gordon R., Northey A., Cirino M. Metters K. M., and Chan C. C. (1999), Distribution and regulation of cyclooxygenase-2 in carrageenaninduced inflammation. Br. J. Pharmacol. 128, 853-859.

Netti C., Bandi G. L., and Pecile A. (1972), Antiinflammatory action of proteolytic enzymes administered orally compared with antiphlogistic compounds. Farmaco 27, 453-466.

Salvemini D., Wang Z.-Q., Wyatt P. S., Bourdon D. M., Marino M. H., Manning P. T., and Currie M. G. (1996), Nitric oxide: a key mediator in the early and 
late phase of carrageenan-induced rat paw inflammation. Br. J. Pharmacol. 118, 829-838.

van der Hoorn R. A. and Jones J. D. (2004), The plant proteolytic machinery and its role in defence. Curr. Opin. Plant Biol. 7, 400-407.

Vellini M., Desideri D., Milanese A., Omini C., Daffonchio L., Hernandez A., and Brunelli G. (1986), Possible involvement of eicosanoids in the pharmacological action of bromelain. Arzneim.-Forsch./Drug Res. 36, 110-112.

Vinegar R., Schreiber W., and Hugo R. (1969), Biphasic development of carrageenan edema in rats. J. Pharmacol. Exp. Ther. 166, 96-103.
Wen S., Huang T. H. W., Li G. Q., Yamahara J., Roufogalis B. D., and Li Y. (2006), Bromelain improves decrease in defecation in postoperative rats: modulation of colonic gene expression of inducible nitric oxide synthase. Life Sci. 78, 995-1002.

Winter C. A., Risley E. A., and Nuss G. W. (1962), Carrageenan-induced edema in hind paw of the rat as an assay for antiinflammatory drugs. Proc. Soc. Exp. Biol. Med. 111, 544-547. 